\title{
Impact of caecotrophy on the performance, nutrient digestibility and blood parameters of growing rabbits
}

${ }^{* 1}$ Salami, S. A., ${ }^{2}$ Isah, O. A., ${ }^{2}$ Aderinboye, R. Y., ${ }^{3}$ Ajayi, L. O. and ${ }^{1}$ Ashi, S.

${ }^{I}$ National Biotechnology Development Agency, Federal Capital Territory, Abuja

${ }^{2}$ Department of Animal Nutrition, College of Animal Science and Livestock

Production, Federal University of Agriculture, PMB 2240, Abeokuta,

${ }^{3}$ Department of Veterinary Pathology, College of Veterinary Medicine, Federal

University of Agriculture, PMB 2240, Abeokuta, Nigeria

Abstract

*Corresponding author: salami.suliata@pg.funaab.edu.ng

A 42-days trial was conducted to investigate the effect of caecotrophy on performance, apparent nutrient digestibility and blood parameters in growing rabbits. Thirty-six crossbred rabbits with an average initial weight of $875 \pm 25 \mathrm{~g}$ were divided into 2 groups (collared and uncollared). The collared group was prevented access to their caecotropes (soft faeces) while the uncollared group were allowed access. Each group had 18 animals with 3 growing rabbits per group, replicated 6 times in a completely randomised design (CRD). The result of the study showed that the uncollared group had higher $(P<0.05)$ final live weight, daily weight gain, feed intake which were, $1.76 \mathrm{~kg}, 17.00 \mathrm{~g} /$ day, $50.6 \mathrm{~g} /$ day, respectively when compared with the collared group which recorded $1.53 \mathrm{~kg}, 11.7 \mathrm{~g} /$ day and $41.7 \mathrm{~g} /$ day respectively. Also, lower $(P<0.05)$ values were recorded for feed conversion ratio and mortality in uncollared rabbits in comparison to their collared counterparts. The ash and crude protein digestibility were higher $(P<0.05)$ in the uncollared group. Serum total protein and albumin were higher in uncollared group while globulin was higher in collared group while Urea and AST was lower in uncollared group. Haematological parameters were not affected by caecotrophy. It can be concluded that prevention of caecotrophy has detrimental effect on the performance, nutrient digestibility and serum biochemical parameters of growing rabbits

Keywords: Caecotropes, growth, nutrient utilisation, haematology, rabbits

\section{L'Impacte de la caécotrophie sur la performance, la digestibilité des nutriments et les paramètres sanguins des lapins en croissance}

\section{Résumé}

Un essai de 42 jours a été mené pour étudier l'effet de la caecotrophie sur la performance, la digestibilité apparente des nutriments et les paramètres sanguins chez les lapins en croissance. Trente-six lapins croisés d'un poids initial moyen de $875 \pm 25$ g ont été divisés en 2 groupes (à collier et non-collier). Le groupe à collier a été empêché d'accéder à leurs caecotropes (excréments mous) tandis que le groupe non collier a été autorisé à y accéder. Chaque groupe avait 18 animaux avec 3 lapins en croissance par groupe, répliqués 6 fois dans un design complètement randomisé (CRD). Le résultat de l'étude a montré que le groupe non collier avait un poids réel final plus élevé $(P<0,05)$, un gain de poids quotidien, une consommation d'aliments qui étaient de $1,76 \mathrm{~kg}, 17,00 \mathrm{~g} / \mathrm{jour}, 50,6 \mathrm{~g} / \mathrm{jour}$, respectivement par rapport au groupe à collier qui enregistrait respectivement 1,53 kg, 11,7 $g / j o u r$ et 41,7 g/jour. De plus, des valeurs inférieures $(P<0,05)$ ont été enregistrées pour le ratio de conversion des aliments et la mortalité chez les lapins noncollier par rapport à leurs homologues à collier. La digestibilité des cendres et des protéines brutes était plus élevée 
$(P<0,05)$ dans le groupe noncollared. La protéine totale de sérum et l'albumine étaient plus élevées dans le groupe noncollier tandis que la globulin était plus élevée dans le groupe collier tandis que l'urée et l'AST étaient plus bas dans le groupe noncollier. Les paramètres hématologiques n'ont pas été affectés par la caecotrophie. On peut conclure que la prévention de la caecotrophie a un effet néfaste sur la performance, la digestibilité des nutriments et les paramètres biochimiques sériques des lapins en croissance Mots-clés:Caecotropes, croissance, utilisation des nutriments, hématologie, lapins

\section{Introduction}

Rabbits excrete two types of faeces; the hard faeces which are commonly seen, are produced in the large intestine. The faeces that are consumed directly from the anus are the soft faeces or caecotropes and they are produced in the caecum (McNitt et al., 1996). The practice of consuming caecotropes is referred to as caecotrophy. The act of caecotrophy in rabbit is essentially a basic practice which allows the use of certain nutrients microbial origin, which are normally excreted with faeces (Peralta et al., 2004). It allows rabbits to utilise microbial cells content of the caecotropes (soft faeces) which contains approximately $28 \%$ CP (Stevens and Hume, 1995). By consuming its soft faeces, a rabbit obtains a significant amount of water-soluble vitamins and up to $20 \%$ of its crude protein $(\mathrm{CP})$ requirements, $30 \%$ of its energy requirements as volatile fatty acids and $18 \%$ of its daily dry matter intake (Lebas et al., 1997). Lebas etal. (1998) also reported that re-ingestion of soft faeces enables the rabbit to meet the maintenance requirement for vitamins of the B-group and other valuable nutrients.

However, conditions, such as small cage size (Peralta et al., 2004) sickness, bad management, stress, tooth problem, injury in the anus and dietary composition (Harcourt-Brown, 2002) may arise in the course of rabbit production and this can lead to a decrease or complete inhibition of caecotrophy. When rabbits are deprived access to their caecotropes, the nutritional benefits derived from the practise are lost and consequently imparts negative effect on the rabbit. Suffice to say, that the implications of uneaten soft faeces for the welfare of rabbits and the profitability of producers are far reaching. However, reports on the actual effect of deprived access to caecotropes are scarce thus this study investigated the effects of caecotrophy on performance characteristics, apparent nutrient digestibility, haematological and serum biochemical parameters in growing rabbits.

\section{Materials and methods \\ Design of plastic collar}

The diameter of the neck of the rabbits was taken with the aid of a measuring tape and the dimension was cut out as a round hole on a flat ( $2 \mathrm{~mm}$ thick) plastic plate with (mean external diameter average: $25.0 \mathrm{~cm}$, weight: $50 \mathrm{~g}$ ). A sharp hot knife was used to split one edge of the plastic into two and holes were punched at side of split edge to accommodate a copper wire. The split edge of the plate was opened and fitted unto the rabbit's neck and copper wire (inserted into the holes) were used to tie the edges in order to prevent removal by rabbits and allow removal by man at the expiration of the experiment.

\section{Experimental animals, management and} design

Thirty-six cross bred rabbits with age range of 8-10 weeks and an initial live weight of $875 \pm 25 \mathrm{~g}$, were housed individually in a wooden hutch measuring $0.85 \times 0.65$ $\mathrm{x} 0.50 \mathrm{~m}$. The animals were allowed for 4day adaptation to the cage, and diet, rabbits were divided into two groups; The collared 
group which were deprived access to their caecotropes with the aid of an improvised plastic collar fitted around the neck and the uncollared group which were allowed to practice caecotrophy and the collared group which were not allowed access to their caecotropes. Each group had 18 animals with 3 growing rabbits per group replicated 6 times in a completely randomised design (CRD). Feed and water were given ad libitum. The ingredient composition of the diet fed is shown on Table 1 while the proximate composition is shown on Table 2. The drinking and feeding troughs were made of earthen pot re-enforced with cement to prevent tipping off and were of removable types for easy cleaning. A total of $100 \mathrm{~g}$ of feed divided into two portions of
$50 \mathrm{~g}$ in the morning 8.00 hour and $50 \mathrm{~g}$ in the evening 16:00 hour was supplied to each rabbit per day. Left over feed was collected and weighed the following morning in order to determine feed intake. Water was provided ad libitum. For 4 days after fitting collars, feed intake and faecal excretion were reduced, and losses in weight and depression were also observed. Feed intake and faecal excretion were only restored to normal after 4 days therefore, experimental data were only recorded after a 4- day adaptation time to the collar. The rabbits were weighed at the start of the experiment and thereafter they were weighed weekly to determine weight gain. The experiment lasted for 42-days.

Table 1: Composition of experimental diets (g/100g DM)

\begin{tabular}{ll}
\hline Feed ingredients & \% composition \\
\hline Maize & 25.00 \\
Soya bean meal & 17.00 \\
Fish meal $(72 \% \mathrm{CP})$ & 0.00 \\
Wheat offal & 26.00 \\
Rice husk & 14.00 \\
Maize offal & 14.00 \\
Oyster shell & 1.50 \\
Bone meal & 1.50 \\
Vitamin premix & 0.50 \\
Salt $(\mathrm{NaCl})$ & 0.50 \\
Total & $\mathbf{1 0 0 . 0 0}$ \\
\hline
\end{tabular}

Premix composition per Kg diet: vit A: 4000000IU, vit D: $800000 I U$, vit E: $40000 \mathrm{mg}$, vit $K_{3}: 800 \mathrm{mg}$, vit $B_{1}: 1000 \mathrm{mg}$, vit $B_{2}: 6000 \mathrm{mg}$, vit $B_{6}: 5000 \mathrm{mg}$, vit $B_{12}: 25 \mathrm{mg}$, Niacin: $6000 \mathrm{mg}$, Panthothenic acid: $2000 \mathrm{mg}$, Folic acid: 200mg, Biotin: $8 \mathrm{mg}$, Manganese: 300000mg, Iron: 8000mg, Zinc: 20000mg, Cobalt: 80mg, Iodine: 400mg, Selenium: 40mg, Choline: $800000 \mathrm{mg}$.

Table 2: Proximate composition of experimental diet

$\begin{array}{ll}\text { Metabolizable Energy }(\mathrm{Kcal} / \mathrm{kg}) & 2500.00 \\ \text { Crude protein (\%) } & 14.95 \\ \text { Crude fibre (\%) } & 7.31 \\ \text { Ash (\%) } & 10.52 \\ \text { Crude fat (\%) } & 4.09 \\ \text { Dry matter (\%) } & 88.15\end{array}$

\section{Measurement of apparent nutrient digestibility}

At the end of 6th weeks two rabbits per replicate were selected for metabolic trials. The rabbit hutch was fitted individually with removable faecal collection trays lined with polythene mesh. The polythene mesh served to prevent mixture of voided faeces with urine. Each rabbit was given known weights of experimental diets for a period of five days during which faecal droppings were collected, according to European 
reference method for rabbit digestion trials (Perez et al., 1995). The faeces collected from each rabbit was pooled together after 5days. Representative samples of faeces, feed and urine were taken for analysis of proximate constituents according to A.O.A.C (1995) procedures.

\section{Collection and analyses of blood samples}

On day 42 days of the experiment, about $2.5 \mathrm{ml}$ of blood was collected through the jugular vein of two randomly selected rabbits from each treatment replicate for haematological analyses. The blood samples were collected into bottles containing ethylene diamine tetra- acetate (EDTA) for analysis of haemoglobin ( $\mathrm{Hb}$ ), red blood cell (RBC), white blood cell (WBC) and packed cell volume (PCV). Another $2.5 \mathrm{ml}$ of blood was collected in hypodermic syringe to obtain serum for determination of biochemical analytes. The activities of alkaline phosphatase (ALP), total bilirubin, total protein, albumin, aspartate aminotransferase (AST), alanine aminotransferase (ALT), creatinine and blood urea nitrogen (BUN) were determined according to the methods described by Reitman and Frankel (1957). Commercial Randox kits (Randox laboratories UK) were used for all serum metabolite analyses

\section{Statistical analysis}

Data collected were subjected to analysis of variance (ANOVA) using SAS (1999) package and the level of significance was determined at 5\%. Differences between significant means were separated using Duncan's multiple range test (1955).

\section{Results and discussion}

Figure 1 shows the effects of caecotrophy on the performance characteristics of growing rabbits. Except FCR, the improvement $(\mathrm{P}<0.05)$ in the performance characteristics (live weight, weight gain and feed intake) were better in uncollared rabbits in comparison with the collared group. This observation confirms earlier report by Allaby (1999) and were indicative of the fact that rabbits without access to their caecotropes were deprived of certain vitamins and amino acids (synthesized by the caecal microflora) that are necessary for optimum nutrition (Harcourt-Brown, 2002) thereby increase performance. Lower $(\mathrm{P}<0.05)$ weight gain and increased $(\mathrm{P}<0.05)$ feed conversion ratio observed in collared rabbits was in consonance with the observations of Robinson et al. (1985 and 1986) using an adapted metabolic cage and Phiny and Kaseonmbath (2006) using a plastic collar to prevent caecotrophy. The result of the current study also indicated that uncollared rabbits had a higher $(\mathrm{P}<0.05)$ feed intake when compared to the collared group. This observation runs contrary to the findings of Phiny and Kaseonmbath (2006) who found no difference in the feed intake of rabbits with or without access to caecotropes. This difference in observation may be due to differences in length of experimental period as 6 weeks was used for the current study against the 4 weeks used by the previous author. Differences in the type of diet fed to experimental rabbits (concentrate against forage fed in the former study) and type of collar (Gidenne and Lapannouse, 2000) may have also contributed to the differences in observations in both studies. Higher percentage mortality in uncollared rabbit also suggests that caecotropes furnish the rabbits with nutrients which were critical to the very existence of the rabbits.

Figure 2 presents data collected on the apparent nutrient digestibility in collared and uncollared rabbits. Higher $(\mathrm{P}<0.05)$ values of coefficients of apparent digestibility of crude protein and ash observed in uncollared rabbits when compared to collared rabbits is in agreement with the report of Elsayaad et al. (1995 and 
1998). The authors found that values of all nutrient digestibility (DM, CP, CF and NFE) for rabbits practising caecotrophy were significantly higher than those prevented from having access to their soft faeces. This observation may help to explain why rabbits have a better utilisation of protein from forages than other nonruminant species. According to Raharjo et al., (1990) a second passage of food through the gut helps to combat the problem of fast feed transit time that limits the optimum use of nutrient. Increased CP digestibility may also be attributed to increased efficiency of microbial degradation and efficiency of synthesis of amino acids that was obtained from eating caecotropes. However, this study found no differences $(\mathrm{P}>0.05)$ in the Dry matter, crude fibre and ether extract digestibility contrary to the observations of Elsayaad et al. (1995 and 1998). This may be due to the nutritional composition of the feed given to the rabbits in both experiments Pinheiro (2002) reported that the nutritional importance of caecotrophy varies according to the nutritional characteristics of diet

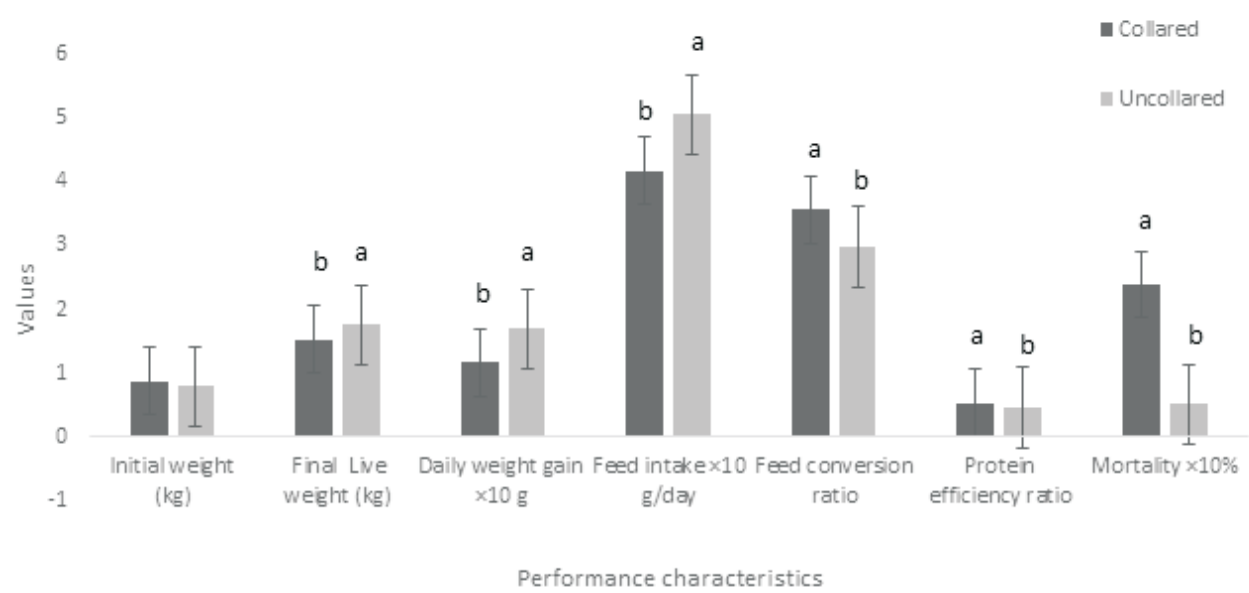

Figure 1: Effect of caecotrophy on Performance characteristics of growing rabbits

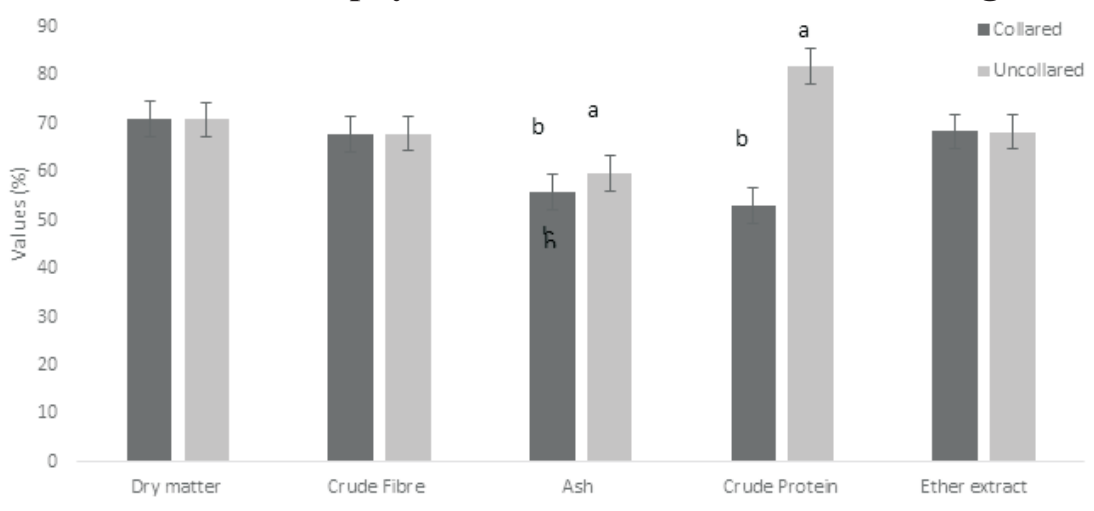

Apparent Nutrient digestibility

Figure 2: Effect of caecotrophy on apparent nutrient digestibility in growing rabbits 
The result revealed no significant $(\mathrm{P}>0.05)$ difference in all the haematological parameters amongst the collared and uncollared rabbit groups. The values obtained for PCV, Hb, WBC, and RBC from rabbits with and without access to caecotropes fell within the normal range $\left(30-50 \%, 9.4-17.4 \mathrm{~g} / \mathrm{dl}, 2.6-12.5 \mathrm{~mm}^{3}\right.$ and $3.8-10.0 \mathrm{~mm}^{3}$ for PCV, Hb, WBC and RBC respectively) healthy rabbits in tandem with Harcourt-Brown (2002) and Kathy (2003)The concentration of serum protein at any given time is a function of the nutritional status, water balance, and other factors affecting the state of health of the animal. Higher $(\mathrm{P}<0.05)$ Serum total protein and albumin concentration observed in uncollared rabbits may suggest that the practice of caecotrophy increase helps to improve the nutritional and health status of rabbits These observations may be explained by the fact that serum protein and albumin synthesis are related to the amount of available protein in the diet (Iyayi and Tewe, 1998). This was in agreement with earlier observed increased crude protein digestibility in rabbits having access to their caecotrope, Lower $(\mathrm{P}<0.05)$ serum urea and AST in uncollared rabbits suggests that caecotropes imparts no damages to the rabbits.

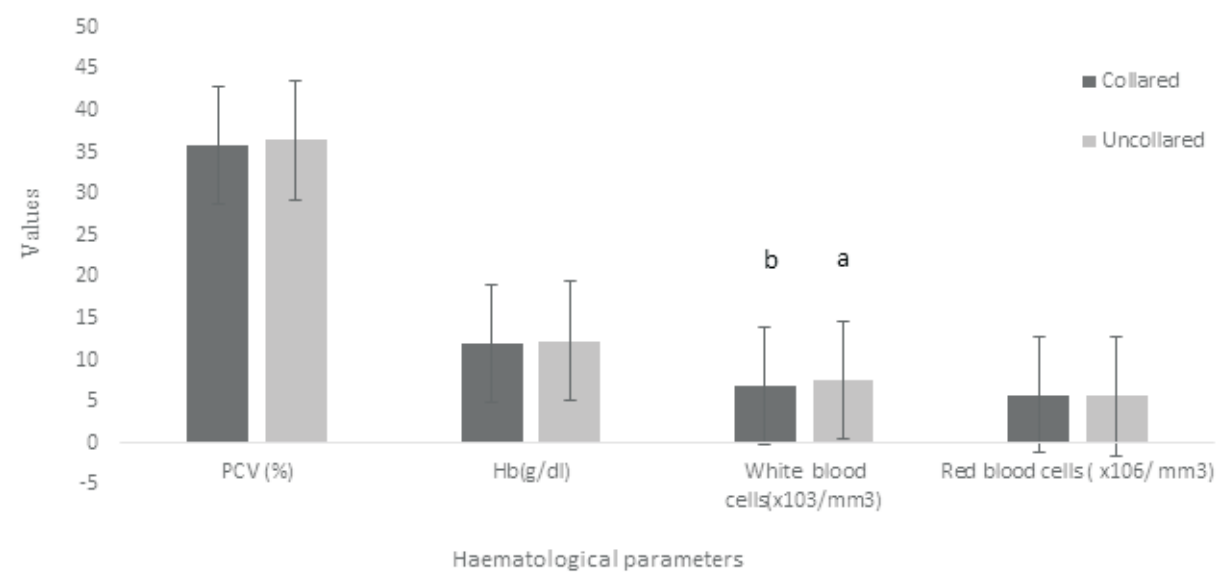

Figure 3: Effect of caecotrophy on haematological parameters in growing rabbits

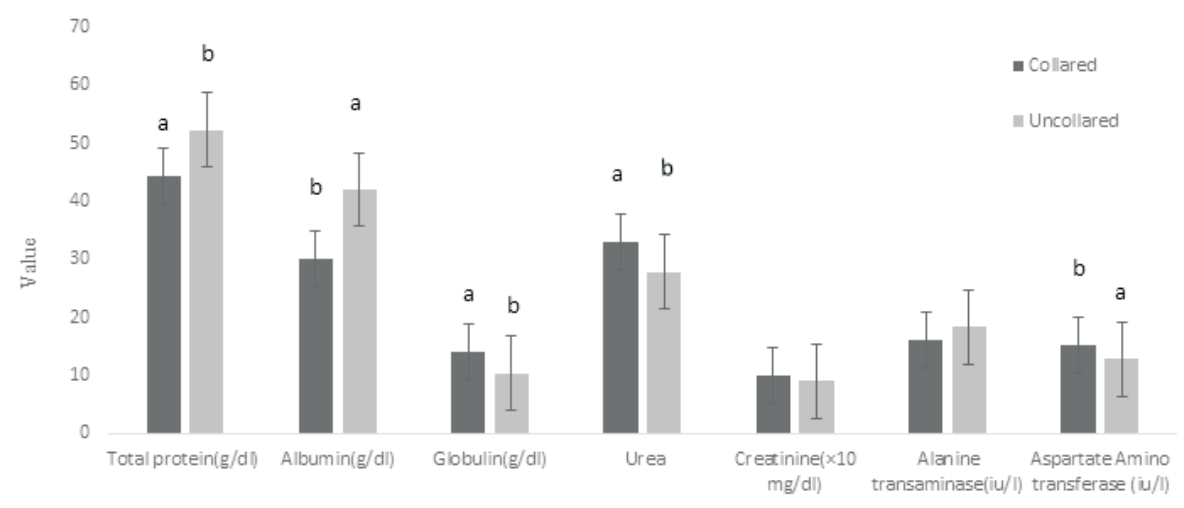

Serum biochemical parameters

Figure 4: Effect of caecotrophy on serum biochemical parameters in growing rabbits 145 


\section{Conclusion}

In conclusion, the present study shows that denied access to caecotropes/soft faeces has far reaching consequences on performance characeristics, apparent nutrient digestibility and serum biochemical parameters of growing rabbits. This effect may be more pronounces after a long period. Thus, occasions that may lead to uneaten faeces should be avoided as much as possible and in case of occurrence it should urgently addressed.

\section{References}

Allaby, M. 1999. "Caecotrophy." A Dictionary of Zoology. 1999. Encyclopedia.com. $20: 2011$.

A.O.A.C. 1995. Association of Official Analytical Chemist. Official Methods of Analysis, 16th edition, Washington D.C.USA.

EISayaad, G. A. E., EIMahdy, M. R. and Soliman, A. S., 1995. Artichoke bracts as a food processing waste product in growing rabbit diets. Egyptian Journal of Rabbit Science 5(2), 125-133.

ElSayaad, G.A.E., Soliman, A.F. and Kh ayyal, A.A.M., 1998 . Nutritional evaluation of sun dried rabbit manure in growing rabbit diets. Egyptian Journal of Rabbit Science, 8(2), 169-182.

Gidenne, T. and Lapanouse, A., 2000. Technical note: The measurement of soft faeces production is affected by the type of collar. World Rabbit Science 8 (1), 41-42.

Harcourt-Brown, F., 2002. The textbook of rabbit medicine, $4^{\text {th }}$ edition. pp. 28-30 Butterworth Heinemann education

Iyayi, E. and Tewe, O. O., 1998. Serum total protein urea and creatine levels as indices of quality of cassava diets for pigs. Tropica Veterinaria. 16: 59-67.
Kathy, S., 2003. Rabbit health in the $21^{\text {st }}$ century. $2^{\text {nd }}$ edition. A guide to bunny parents. pp 131-140.

Lebas, F., Coudert, P., Rochambeau, H. F. and Thébault, R. G. 1997. The Rabbit Husbandry, Health and Production. FAO Animal Production and Health Series No. 2 http://www.fao.org/docrep/t1690E t1690E00.htm.

Lebas, F., Gidenne, T., Perez, J. M. and Licois, D. 1998. Nutrition and pathology. In: The Nutrition of the Rabbit deBlas C., Wiseman $J$. (ed.), CABI Publishing, CAB.

McNitt, J.I., Cheeke, P.R., Patton, N.M. and Lukefahr, S. D. 1996. Rabbit Production. Interstate Publishers, Inc., Danville, IL.

Peralta, A. M., Carlos, G. O., David, H. S., Sergio, S. G., MuñozGermán, D. and Mendoza, M., 2004. Isolation and characterization of two rabbit caecum bacteria with potential use for rabbit feeding in Veterinaria Méxicojourna 2(35),

Perez ,J. M., Lebas , F., Gidenne, T., Carabano, R., Fraga, M. J., Blas, E., and Freire, J., 1995. European reference method for in vivo determination of diet digestibility in rabbits. World Rabbits Science 3, $41-43$.

Phiny, C. and Kaensombath, L., 2006. Effect on feed intake and growth of depriving rabbits access to soft faeces, Livestock Research For Rural Development. 18, ( 34 ). R e tri e ved from http://www.cipav.org.co/1rrd/lrrd1 8/3/phin18034.htm

Pinheiro, V., 2002. Contributo para o estudo da digestão nos coelhos: efeito do teor em fibra e da natureza do amido da dieta. Ed. UTAD. Vila Real. 1, 254. 
Impact of caecotrophy on the performance, nutrient digestibility and blood parameters of growing rabbits

Raharjo, Y. C., Cheeke, P. R. and Potton, N. M., 1990. Effect of caecotrophy on the nutrient digestibility of Alfalfa an black locust leaves. Journal of Applied Rabbit Research, 13: 56-61.

Reitman, S., Frankel, S. A. 1957. Colorimetric method for the determination of serum glutamic oxalacetic and glutamic pyruvic transaminases. American Journal of Clinical Pathology, 28:56-63
SAS, 1999. SAS/STAT User's Guide. Version 8.0 SAS Institute Inc., Carry, North Carolina, USA.

Stevens, C. E. and Hume, I. D., 1995. Comparative physiology of the vertebrate digestive System. 2nd ed. Cambridge University Press, Cambridge, United Kingdom.

Received: $17^{\text {th }}$ October, 2020

Accepted: $5^{\text {th }}$ February, 2021 